Article

\title{
High Dosage Lithium Treatment Induces DNA Damage and $557^{\mathrm{Kip} 2}$ Decrease
}

\author{
Emanuela Stampone ${ }^{\dagger}$, Debora Bencivenga ${ }^{+}(\mathbb{D}$, Clementina Barone, Arianna Aulitto, \\ Federica Verace, Fulvio Della Ragione* and Adriana Borriello *D \\ Department of Precision Medicine, University of Campania “Luigi Vanvitelli”, 80100 Naples, Italy; \\ emanuela.stampone@unicampania.it (E.S.); debora.bencivenga@unicampania.it (D.B.); \\ clementina.barone@unicampania.it (C.B.); arianna.aulitto@unicampania.it (A.A.); \\ federicaverace@gmail.com (F.V.) \\ * Correspondence: adriana.borriello@unicampania.it (A.B.); fulvio.dellaragione@unicampania.it (F.D.R.); \\ Tel.: +39-0815667554 (A.B.); +39-0815665812 (F.D.R.) \\ + These authors contributed equally to this work.
}

Received: 15 December 2019; Accepted: 7 February 2020; Published: 10 February 2020

\begin{abstract}
Lithium salt is the first-line therapeutic option for bipolar disorder and has been proposed as a potential antitumoral drug. The effects of $\mathrm{LiCl}$ treatment were investigated in SH-SY5Y, a human neuroblastoma cell line and an in vitro model of dopaminergic neuronal differentiation. $\mathrm{LiCl}$, at the dosage used in psychiatric treatment, does not affect cell proliferation, while at higher doses it delays the SH-SY5Y cell division cycle and for prolonged usage reduces cell viability. Moreover, the ion treatment affects DNA integrity as demonstrated by accumulation of p53 and $\gamma \mathrm{H} 2 \mathrm{AX}$ (the phosphorylated form of H2AX histone), two important markers of genome damage. p57 Kip2, a $\mathrm{CIP} / \mathrm{Kip}$ protein, is required for proper neuronal maturation and represents a main factor of response to stress including genotoxicity. We evaluated the effect of lithium on $\mathrm{p} 57^{\mathrm{Kip} 2}$ levels. Unexpectedly, we found that lithium downregulates the level of p57 $7^{\mathrm{Kip} 2}$ in a dose-dependent manner, mainly acting at the transcriptional level. A number of different approaches, mostly based on $\mathrm{p} 57^{\mathrm{Kip} 2}$ content handling, confirmed that the CKI/Kip reduction plays a key role in the DNA damage activated by lithium and suggests the unanticipated view that $\mathrm{p} 57^{\mathrm{Kip} 2}$ might be involved in DNA double-strand break responses. In conclusion, our study identified novel roles for p57 Kip2 in the molecular mechanism of lithium at high concentration and, more in general, in the process of DNA repair.
\end{abstract}

Keywords: p57Kip2; LiCl; SH-SY5Y; oxidative stress; DNA damage; DNA damage response

\section{Introduction}

Since the last century, the therapeutic importance of lithium has been investigated, and many benefits of its use have been reported [1,2]. The main medical use of Li treatment is mental illness. Indeed, Li salt represents a well-established therapeutic option for bipolar disorder; it is also employed in schizophrenia, major depression, and in several psychiatric diseases when other treatments fail [3]. However, numerous toxic side effects were observed, only partially solved by the adjustment of the employed doses [2]. Safe therapeutic lithium blood levels range from 0.6 to $1.2 \mathrm{mM}$, while lithium toxicity can be observed when the serum concentration reaches $1.5 \mathrm{mM}$ or higher [2].

Molecular mechanisms underlying $\mathrm{Li}$ action are complex and not completely clarified. This might be mostly due to the pleiotropy of Li molecular effects. So far, in vitro and in vivo studies have proposed that Li modulates several key enzymes and biochemical pathways in the nervous system, including inositol monophosphatase (IMP) [4], adenylyl cyclase [5], protein kinase C [6], phosphatidylinositol 3-kinases (PI3K)/AKT/glycogen synthase kinase 3 (GSK3), and WNT/beta-catenin 
pathways [7,8]. A main activity of $\mathrm{Li}$ is the inhibition of GSK3 $\beta$ [9], a serine/threonine kinase involved in many processes such as insulin response, cytoskeletal organization, and apoptosis [10]. However, none of the proposed biochemical mechanisms is sufficient to explain alone Li functions.

Due to the fact of its relevant and well-established inhibition activity on pro-survival and pro-proliferative kinases, the use of $\mathrm{LiCl}$ in cancer therapy has also been exploited. Lithium treatment reduces the viability of several cancer cell lines of different origin, such as neuroblastomas and prostate and colon cancers [11-13], mainly through the induction of programmed cell death.

Mechanistically, it has been suggested that $\mathrm{LiCl}^{\prime}$ s putative effects rely on the ability to interfere with several cellular processes and activities, such as the redox state, mitochondrial function, autophagy, DNA damage (DD), and the consequent cellular response (generally defined as DNA damage response or DDR) [14-16]. As a matter of fact, the maintenance of genome stability is a cornerstone of normal cell homeostasis, and DDR pathways ensure genome integrity [17]. DD has been associated with the pathophysiology of psychiatric disorders, like bipolar disorder [18], and with neurodegenerative pathologies such as Alzheimer's and Parkinson's [19]. In these syndromes, defects of DDR systems have been found to exacerbate amyloid precursor pathological action [19]. Genotoxic stress and apoptosis induction are also general mechanisms of anti-cancer drugs. There is evidence that the administration of Li salts to cultured cells promotes DD and, subsequently, the DDR initiation $[15,16]$.

Molecularly, DD induces the activation of the DNA damage-sensing serine/threonine kinases ataxia-telangiectasia mutated (ATM) and ATM- and Rad3-related (ATR) kinases which are considered the master transducers of DNA signals, together with DNA-PKcs (DNA-dependent protein kinase, catalytic subunit). All these kinases are members of the phosphatidylinositol-3-kinase-like kinases (PIKKs) family [20] and might activate an ample network of signal transduction pathways able to maintain genome integrity. Among them, the phosphorylation, mainly due to the ATM, of the histone variant $\mathrm{H} 2 \mathrm{AX}$ on Ser139, forming $\gamma \mathrm{H} 2 \mathrm{AX}$, is required to initiate a chromatin-based signaling cascade which activates the recruitment of DDR proteins at the lesion's region [21]. In parallel, p53 signaling may be activated to induce cell cycle arrest, apoptosis, and/or senescence effector proteins [22,23]. One well-known p53 target gene is CDKN1A that encodes p21 ${ }^{\mathrm{Cip} 1}$, a cyclin-dependent kinase (CDK) inhibitor (CKI), which binds to the cyclin-CDK complexes and inhibits their activity, leading to cell cycle arrest. p21 ${ }^{\mathrm{Cip} 1}$ belongs to the $\mathrm{CDK}$ interacting protein/kinase inhibitory protein (CIP/Kip) CKI family that also includes $27^{\mathrm{Kip} 1}$ and p57 ${ }^{\mathrm{Kip} 2}$ (hereinafter p57) [24]. Among the three siblings, p57, the less characterized family member, has a peculiar role in allowing cell survival upon a variety of stresses [25-28]. Particularly, studies in murine and human cell lines revealed that p57 is part of the cellular stress response under conditions such as oxidative stress and UV exposure [26]. In accord, $C d k n 1 c$ (the mouse gene encoding p57, corresponding to CDKN1C in humans) ablated mice mostly die after birth, exhibiting an increased rate of cellular apoptosis and severe developmental defects, while p21 ${ }^{\mathrm{Cip} 1}$ - and $\mathrm{p} 27^{\mathrm{Kip} 1}-\mathrm{KO}$ mice do not present important growth defects [25].

In addition, in cancer cell lines p57 seems to have a role in chemoresistance [29]. Particularly, in primary rectal cancer cells and in tumor models, it has been shown that doxorubicin administration induces p57 upregulation due to the activation of the ATM pathway. It is to underline that ATM-associated mechanisms are capable of activating the G1/S checkpoint thus preventing apoptosis $[29,30]$. In contrast, the overexpression of p57 has also been correlated in some instances to the promotion of apoptosis in cancer cells $[28,29,31]$. In addition, it has been reported that p57, in parallel with the ability to stabilize the actin cytoskeleton through modulation of cofilin phosphorylation, might translocate into mitochondria promoting Bax activation and the mitochondrial apoptotic cell death pathway [31]. These conflicting observations (favoring cell survival under stress conditions versus activating cell death) suggest a context-specific p57 role in cell death modulation.

In adults, CDKN1C transcription is restricted to some tissues including the nervous system [32]. Furthermore, p57 is highly expressed in several neuroblastoma cell lines [32]. Since in neural cells p57 plays important roles in the response to stress conditions, acting as a pivotal effector molecule of the 
DNA damage response [25-29], and Li activity has been related to DNA damage [12], we investigated the effect of Li on p57 levels/activity in neuroblastoma cells in connection with cell phenotype.

\section{Results}

\subsection{Proliferation Rate and Viability Reduction of SH-SY5Y Cells Induced by LiCl Treatment}

The effects of $\mathrm{LiCl}$ on cell proliferation and cell cycle distribution were investigated in the SH-SY5Y neuroblastoma cell line. Consistent with the data reported in the literature [11-13], $\mathrm{LiCl}$ induced at $24 \mathrm{~h}$ a dose-dependent reduction of cell proliferation (Figure 1A). A time-course experiment was then performed using $25 \mathrm{mM} \mathrm{LiCl}$ and a time interval up to $48 \mathrm{~h}$. A clear growth inhibition was evident after only $8 \mathrm{~h}$ of incubation (Figure 1B). Lithium treatment also modified the cellular morphology (Figure 1C). Particularly, cells exposed to $25 \mathrm{mM} \mathrm{LiCl}$ for $24 \mathrm{~h}$ showed shorter neurite-like protrusions compared to control cells (Figure 1C).

Cell-cycle analysis of SH-SY5Y cells treated with $25 \mathrm{mM} \mathrm{LiCl}$ evidenced an early (after 4 and $8 \mathrm{~h}$ and up to $24 \mathrm{~h}$ ) accumulation in the $\mathrm{S}$ phase with a relevant delay in the progression into G2 phase, suggesting a restraint in overpassing the S/G2 checkpoint. No apoptosis was evident after $24 \mathrm{~h}$ treatment (1\% sub-G1 cells) while, at $48 \mathrm{~h}$ of incubation, apoptosis induction increased with $30 \%$ sub-G1 cells (Figure 1D). Comparatively, cell cycle analysis of SH-SY5Y control cells (i.e., treated with $25 \mathrm{mM} \mathrm{NaCl}$ ) showed the absence of apoptosis and a small reduction of $S$ phase cells. Thus, to study $\mathrm{Li}$ effects in its early stages and to avoid effects due to the apoptosis, $24 \mathrm{~h}$ treatment was chosen for the subsequent investigations. Figure $1 \mathrm{E}$ reports the result of an immunoblotting analysis of poly (ADP-ribose) polymerase-1 (PARP-1), an enzyme that plays a central role in DD repair and whose $90 \mathrm{kDa}$ cleavage product is a recognized marker of apoptosis. As clearly shown, $24 \mathrm{~h} \mathrm{Li}$ exposure did not determine PARP-1 cleavage which was conversely evident when cells were treated with $0.5 \mu \mathrm{M}$ staurosporine (a powerful apoptosis inducer here employed as positive control), alone or in the presence of $25 \mathrm{mM} \mathrm{LiCl}$. We also investigated the effect of $\mathrm{Li}$ on cofilin phosphorylation. Cofilin phosphorylation plays a major role in cytoskeleton remodeling and, accordingly, might be associated to the cell morphology changes (shown in Figure 1C). As reported in Figure 1F, Li clearly increased phospho-cofilin levels.

\subsection{Oxidative and Genotoxic Stress Determined by LiCl Treatment}

The slowing down of the cell cycle progression through the $\mathrm{S}$ phase might be due to the activation of the intra-S checkpoint as a mechanism to safeguard the genome stability from possible genotoxic stress due to the $25 \mathrm{mM}$ Li treatment. At this concentration, Li has been reported to increase DNA damaging reactive oxygen species (ROS) [15].

To confirm that in our cell model Li induces oxidative stress, intracellular ROS levels were measured by dichlorofluorescein (DCF) assay in cells treated with 1 and $25 \mathrm{mM} \mathrm{LiCl}$ for $24 \mathrm{~h}$ (Figure 2A). Cells exposed to tert-butyl hydroperoxide (TBH) for $3 \mathrm{~h}$ were employed as the positive control. While $24 \mathrm{~h}$ treatment with $1 \mathrm{mM} \mathrm{LiCl}$ had no (or scarce) effect in comparison with control cells, a statistically significant increase in the ROS level $(p<0.05)$ in $25 \mathrm{mM} \mathrm{LiCl-treated} \mathrm{cells} \mathrm{was} \mathrm{observed.} \mathrm{We} \mathrm{also}$ evaluated whether enhanced ROS production was involved in Li-dependent cellular effects and particularly in its anti-proliferative activity. To this aim, we compared Li effects on cellular growth in the presence or absence of N-acetylcysteine (NAC), a well-known and widely used antioxidant molecule (Figure 2B). The data obtained, demonstrating only a partially protective NAC activity, correlated the Li-dependent ROS production and effect on cell growth but also suggested the occurrence of additional pathways involved in the Li mechanism of action. 

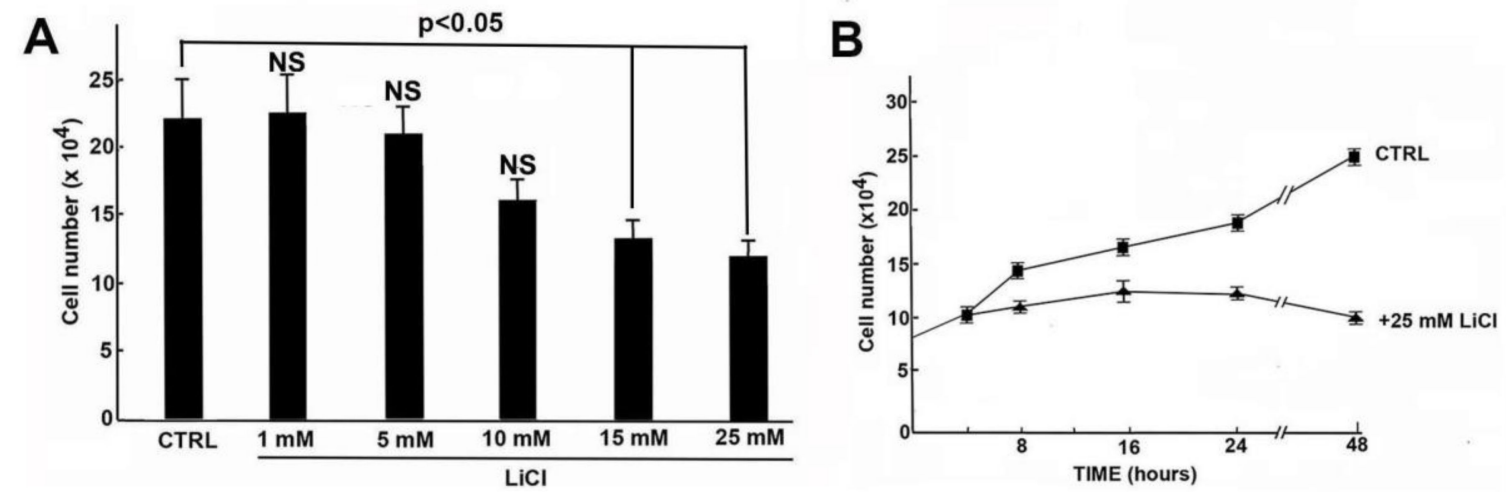

C

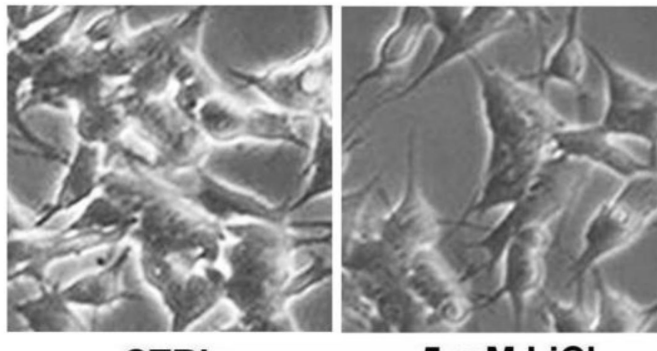

CTRL

$5 \mathrm{mM} \mathrm{LiCl}$

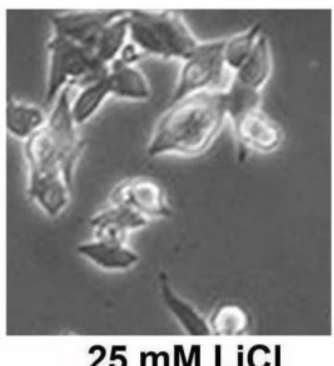

D

E PARP-

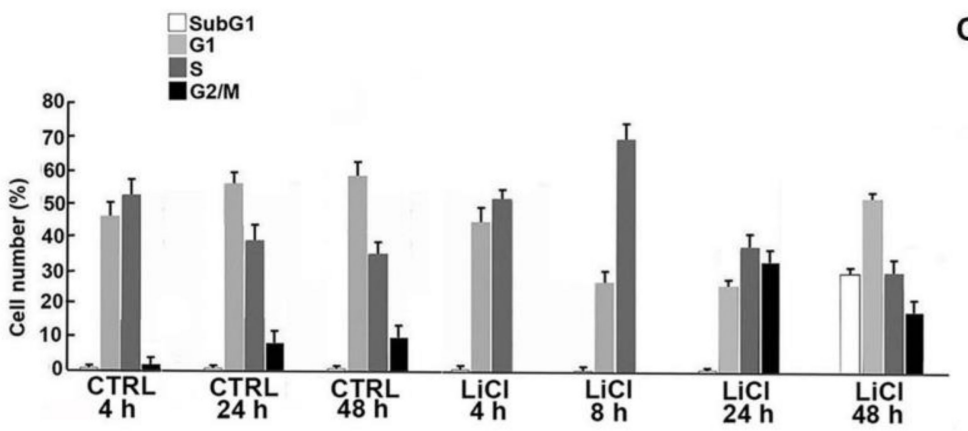

Cleaved PARP-

F

Actin-
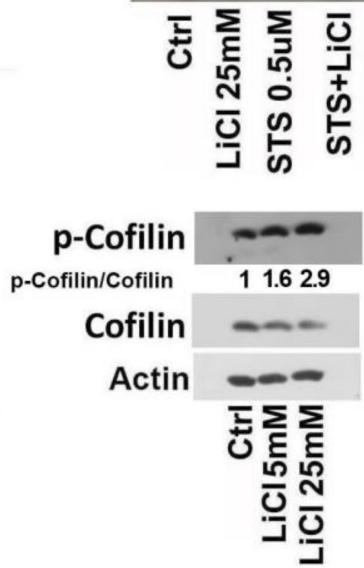
Figure 1. Effect of lithium on the growth and morphology of SH-SY5Y cells. (A) The dose-dependent effect of $\mathrm{LiCl}$ on the proliferation rate of SH-SY5Y cells after $24 \mathrm{~h}$ of incubation was evaluated by direct cell counting. The CTRL value represents the number of cells cultured with $25 \mathrm{mM} \mathrm{NaCl}$. The data shown are the mean of three independent experiments, and the standard deviation ( $\mathrm{T}$ bar) is reported. A $p$-value $<0.05$ denotes a significant difference; NS, lack of significant difference. (B) Effect of $25 \mathrm{mM}$ $\mathrm{LiCl}$ on the growth of SH-SY5Y cells at different incubation times. The data shown are the mean of three independent experiments, and the standard deviation (T bar) is reported. (C) Effect of two different concentrations of $\mathrm{LiCl}(5 \mathrm{mM}$ and $25 \mathrm{mM}$ ) on the morphology of SH-SY5Y cells in comparison with cells grown in the presence of $25 \mathrm{mM} \mathrm{NaCl}$ (CTRL). The images were taken using a Leica DM IRB inverted microscope with an objective $20 \times / 1.5$. (D) Effect of $25 \mathrm{mM} \mathrm{LiCl}$ on the cell cycle phase distribution of SH-SY5Y cells evaluated at different incubation times. CTRL refers to the distribution of cells cultured in presence of $25 \mathrm{mM} \mathrm{NaCl}$ at the reported incubation times. (E) SH-SY5Y cells were treated with $25 \mathrm{mM} \mathrm{NaCl}$ (CTRL), $25 \mathrm{mM} \mathrm{LiCl}$, and $0.5 \mu \mathrm{M}$ staurosporine (STS) for $4 \mathrm{~h}$ and $25 \mathrm{mM} \mathrm{LiCl}$ for $24 \mathrm{~h}$ plus $0.5 \mu \mathrm{M}$ STS added to the medium for the last $4 \mathrm{~h}$ of incubation. After $24 \mathrm{~h}$ treatment, cell extracts were prepared and analyzed by Western blotting using a monoclonal anti-PARP antibody able to detect both full-length PARP1 (116 kDa) as well as the large fragment ( $89 \mathrm{kDa})$ of PARP1 resulting from caspase cleavage. (F) The level of phospho-cofilin was analyzed in protein extracts of SH-SY5Y cells treated with $5 \mathrm{mM}$ and $25 \mathrm{mM} \mathrm{LiCl}$ for $24 \mathrm{~h}$ in comparison with cells grown in the presence of $25 \mathrm{mM} \mathrm{NaCl}$ as CTRL. The ratio between phospho-cofilin and cofilin signal intensities was calculated using ImageJ software (see Materials and Methods, Section 5).

To investigate the possible genotoxic activity of $\mathrm{Li}$, we analyzed the levels of $\gamma \mathrm{H} 2 \mathrm{AX}$ (pS139H2AX), a marker of DNA double-strand breaks (DSBs), in Li-treated cells. As shown in Figure 2C, a dose-dependent increase of $\gamma \mathrm{H} 2 \mathrm{AX}$ immunoreactive signal was observed in Li-exposed SH-SY5Y cells. It is well-known that p53 orchestrates a variety of DNA-damage response mechanisms. Accordingly, we evaluated whether $\mathrm{Li}$ activates the $\mathrm{p} 53 / \mathrm{p} 21^{\mathrm{Cip} 1}$ pathway to arrest cell proliferation and to allow DNA repair. As reported in Figure 2D, a clear increase of both proteins was induced by Li. We also evaluated the effect of $\mathrm{Li}$ on the other Cip/Kip CDK inhibitors. While no significant variation of p27 ${ }^{\mathrm{Kip} 1}$ cell content was evident (Figure 2E), unexpectedly, p57 levels were progressively reduced by Li addition (Figure 2F). Due to both the novelty of the last observation and the proposed key role of p57 in stress response [25-28], we focused our attention on the possible correlation between Li-induced genotoxic effect and Li-dependent p57 downregulation.

First, we confirmed the negative Li effect on p57 cellular content in an additional neuroblastoma cell line, namely, Lan-5 cells (Figure 2G). This N-Myc amplified cell line was selected for comparison with SH-SY5Y cell line that does not show N-Myc amplification. The result obtained in Lan-5 cells suggests that the Li-dependent p57 decrease was not correlated to $\mathrm{N}-\mathrm{Myc}$ status (Figure 2G). Usually, in immunoblotting analyses, p57 signal, as noted in Figure 2F,G, appears as a doublet where, as we recently demonstrated, the upper and slower migrating band corresponds to more phosphorylated isoform(s), while the lower band to hypo- or unphosphorylated form(s) [33]. Interestingly, beside the decrease of p57 total levels, the decline in the p57 upper band signal intensity was particularly evident (Figure 2F,G), suggesting that Li affects p57 phosphorylation. The effect was also observed, although to a minor extent, by transfecting the cells with an expression vector encoding for p57 (p57-pcDNA3.1) and adding, after $8 \mathrm{~h}, 25 \mathrm{mM} \mathrm{LiCl}$ for an additional $24 \mathrm{~h}$. In this experiment, the total amount of the protein was scarcely affected, the p57 expression being controlled by the plasmid promoter (CMV). However, the analysis of the Li-incubated transfected cells showed a decrease of the upper signal associated to the accumulation of the lower band, indicating an effect on protein phosphorylation (Figure 2H). To confirm the effect of Li on p57 phosphorylation, we performed a two-dimensional electrophoresis followed by Western blotting (2D/WB) of extracts from $24 \mathrm{~h} \mathrm{LiCl}$-treated cells compared to the control, namely, $24 \mathrm{~h} \mathrm{NaCl}$-treated cells. The results showed a Li-dependent decrease of the phosphorylated specific isoforms (i.e., those focalizing at more acidic $\mathrm{pH}$ and with a slightly higher apparent MW), corresponding, in the control sample shown in Figure 2I, to the spots numbered from 3 
to 6. Contemporaneously, Li exposure induced an intensification of the signals (spots 1 and 2) specific for the unmodified and hypophosphorylated p57 isoforms, respectively (Figure 2I).
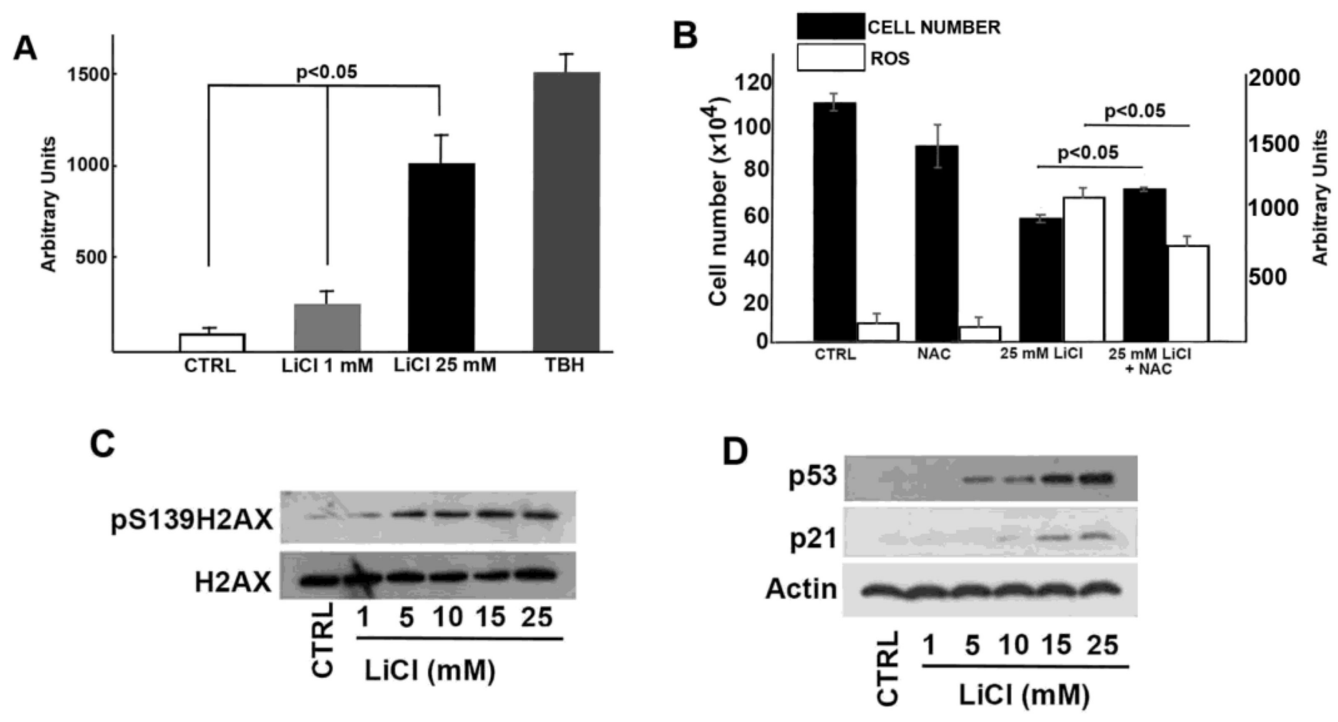

E

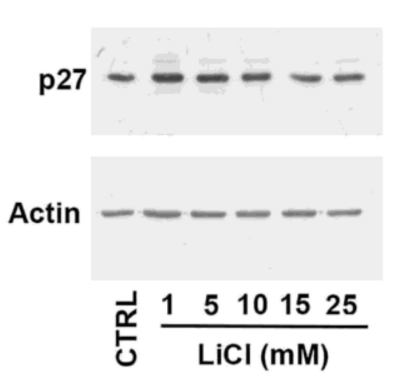

$\mathbf{F}$

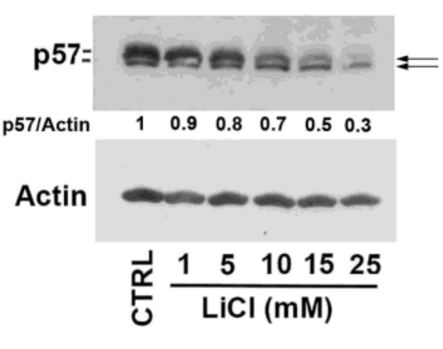

G

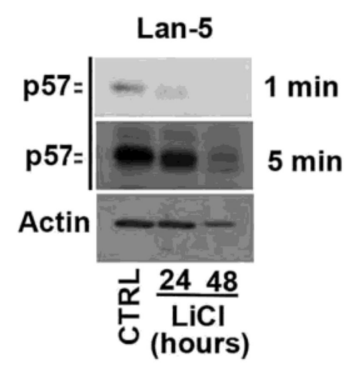

H

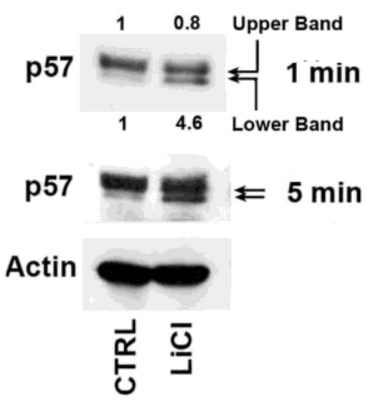

I

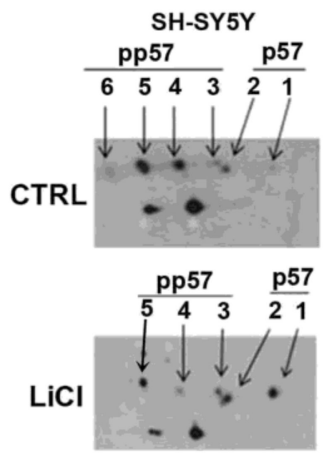


Figure 2. Effect of lithium on ROS production, DNA damage, and p57 cellular content. (A) Effect of different amounts of $\mathrm{LiCl}$ on intracellular ROS level in SH-SY5Y cells. Treatment with $1 \mathrm{mM}$ tert-butyl hydroperoxide (TBH) was used as the positive control. The data shown represent the mean of three independent experiments, and the standard deviation ( $\mathrm{T}$ bar) is reported. A $p$-value $<0.05$ denotes significant difference. (B) SH-SY5Y cells were treated with $25 \mathrm{mM} \mathrm{LiCl}$ in the presence or absence of N-acetylcysteine (NAC). CTRL refers to cells incubated with $25 \mathrm{mM} \mathrm{NaCl}$; NAC represents cells exposed to $25 \mathrm{mM} \mathrm{NaCl}$ plus $150 \mu \mathrm{M}$ NAC. The growth rate was evaluated by direct cell counting after $24 \mathrm{~h}$ incubation. The plot also shows the intracellular ROS levels determined as in (A). Data are the mean of three independent experiments, and the standard deviation ( $\mathrm{T}$ bar) is reported. A $p$-value $<0.05$ denotes a significant difference. (C) Western blotting analysis of the variation of the amount of $\gamma \mathrm{H} 2 \mathrm{AX}$ (pS139H2AX) and H2AX in response to the treatment of SH-SY5Y cells with different amounts of $\mathrm{LiCl}$ for $24 \mathrm{~h}$. CTRL is represented by cells incubated with $25 \mathrm{mM} \mathrm{NaCl}$ for 24 hours. (D) As in panel (C), except that p21 ${ }^{\mathrm{Cip} 1}$ (p21) and p53 were analyzed in the cell extracts. Equal loading of proteins was verified by determining actin content. (E) As in panel (C), except that $\mathrm{p}^{27^{\mathrm{Kip}} 1}$ was analyzed. Actin content was determined to verify equal loading of proteins. (F) As in panel (C), except that p57 levels were analyzed. The ratio between p57 and actin signal intensities is reported. (G) Lan-5 cells were treated with $25 \mathrm{mM} \mathrm{NaCl}$ (CTRL) or with $25 \mathrm{mM} \mathrm{Li}$ for 24 and $48 \mathrm{~h}$, and cell extracts were analyzed for p57 content by immunoblotting. Equal loading of proteins was verified by determining actin content. Films at two different exposure times are shown. (H) SH-SY5Y cells were transfected for $8 \mathrm{~h}$ with $1 \mu \mathrm{g}$ p57-pcDNA3.1 expression vector. Then, $25 \mathrm{mM} \mathrm{NaCl}$ (CTRL) or $25 \mathrm{mM} \mathrm{LiCl}$ were added to the cell media for additional $24 \mathrm{~h}$. Thus, equal amounts of proteins were analyzed for p57 content by immunoblotting. The arrows represent the upper and lower p57 signals. The p57-specific signals were quantified as the ratio of the upper and lower signal over actin signal, respectively. Films at two different exposure times ( 1 and $5 \mathrm{~min}$ ) are shown. (I) SH-SY5Y cells were treated with $25 \mathrm{mM}$ $\mathrm{NaCl}$ (CTRL) or $25 \mathrm{mM} \mathrm{LiCl}$ for $24 \mathrm{~h}$. After the treatment, cell extracts were analyzed for p57 by bidimensional immunoblotting using anti-p57 mouse monoclonal $\mathrm{Ab}$. The isoforms at the upper level correspond to phosphoforms with an increasing number of phosphate moieties (isoforms from 3 to 6). The lower level includes the unmodified form (signal 1) and the phosphoform with one phosphorylated residue (signal 2). Additional details are described in Materials and Methods, Section 5.

\subsection{Molecular Bases of Li-Dependent Effects on p57 Protein}

Since the $\mathrm{p} 57$ protein, same as its siblings $\mathrm{p} 21^{\mathrm{CIP} 1}$ and $\mathrm{p} 27^{\mathrm{Kip} 1}$, plays numerous roles in cell biology depending on subcellular localization and on specific interactors and might also have a different regulation in distinct cell compartments, the nuclear/cytosolic distribution of the protein in cells treated with $25 \mathrm{mM} \mathrm{LiCl}$ for $24 \mathrm{~h}$ was evaluated. As shown in Figure 3A, Li reduced p57 levels in both compartments and particularly in the cytosol. To unravel the molecular mechanisms by which Li treatment reduces p57 levels, we evaluated the effects of $\mathrm{LiCl}(25 \mathrm{mM}$ at $24 \mathrm{~h}$ ) on the transcription of CDKN1C. The results of a real-time RT-PCR experiment, reported in Figure 3B, show approximately a $45 \%$ downregulation of the CDKN1C transcript in treated cells compared to the control. Overall, our findings demonstrate that Li affects p57, both by reducing CDKN1C gene transcription (Figure 3B) and altering protein post-translational modifications (Figure 2I). In addition, we observed that the negative effect mostly affects the protein localized in the cytosolic compartment. 
A

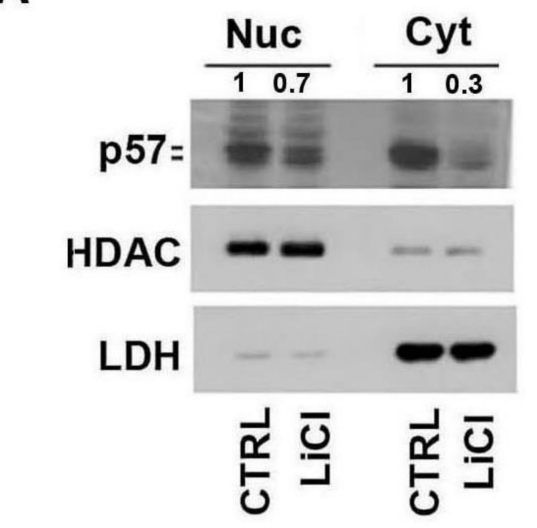

C

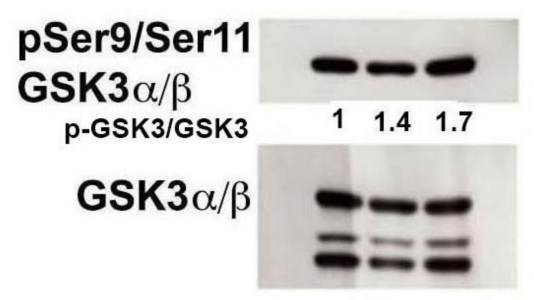

$\beta$-Catenin

Catenin/LDH

$\begin{array}{lll}1.2 & 1.4\end{array}$

LDH

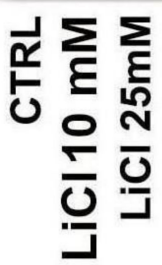

B

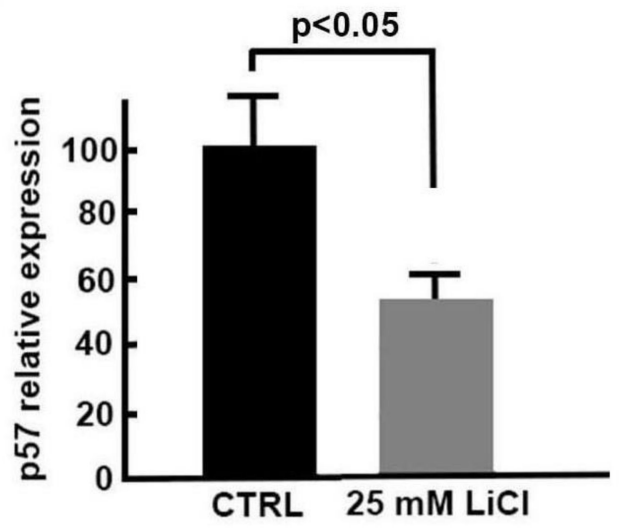

D

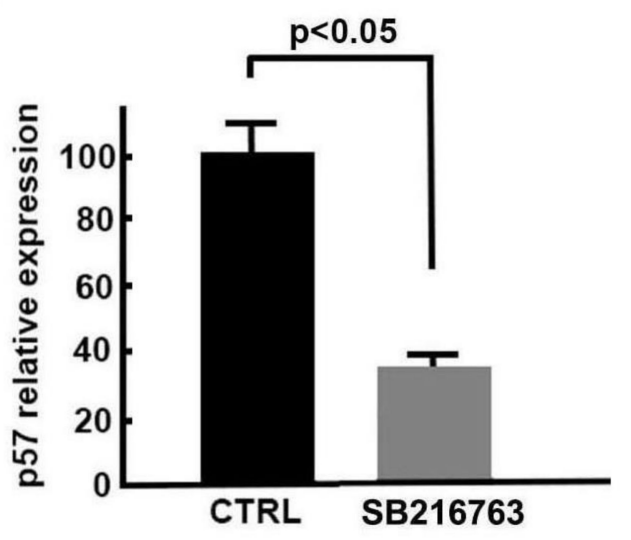

E

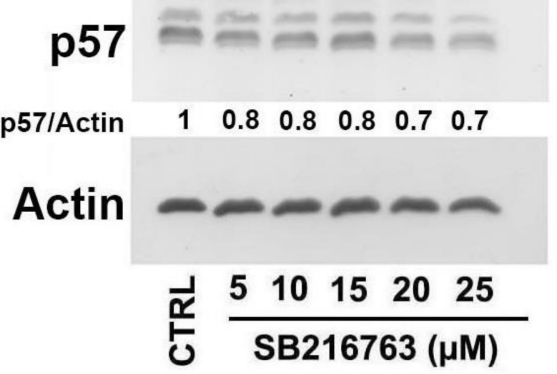


Figure 3. Molecular mechanisms of lithium's effect on p57 content. (A) Immunoblotting analysis of nuclear and cytosolic fractions of SH-SY5Y cells treated with $25 \mathrm{mM} \mathrm{NaCl}$ (CTRL) or LiCl for $24 \mathrm{~h}$. HDAC1 and LDH were analyzed to confirm the efficiency of cell compartment fractionation and equal protein loading. The ratio between p57 and the loading control signal is also reported. (B) SH-SY5Y cells were treated with $25 \mathrm{mM} \mathrm{NaCl}$ (CTRL) or $25 \mathrm{mM} \mathrm{LiCl}$ for $24 \mathrm{~h}$, and the CDKN1C transcript was evaluated by quantitative RT-PCR. The data shown are the mean of three independent experiments, and the standard deviation is reported. A $p$-value $<0.05$ denotes significant difference. (C) SH-SY5Y cells were treated with $25 \mathrm{mM} \mathrm{NaCl}$ (CTRL) and with 10 and $25 \mathrm{mM} \mathrm{LiCl}$ for $24 \mathrm{~h}$. Cell extracts were analyzed for phosphoserine21-phosphoserine9/GSK3 $\alpha / \beta$ (pSer21/pSer9-GSK3 $\alpha / \beta)$ and $\beta$-catenin content by immunoblotting. Equal loading of proteins was verified by determining the LDH content. The ratios between pSer21/pSer9-GSK3 $\alpha / \beta$ and GSK3 $\alpha / \beta$ and $\beta$-catenin and LDH band intensities are also shown. (D) Effect of SB216763 treatment on CDKN1C expression. SH-SY5Y cells were treated with $25 \mu \mathrm{M}$ SB216763 or with the vehicle DMSO (CTRL) for $24 \mathrm{~h}$. CDKN1C expression was evaluated by quantitative RT-PCR. The data shown are the mean of three experiments, and the standard deviation is reported. A $p$-value $<0.05$ denotes a significant difference. (E) SH-SY5Y cells were treated with different amounts of SB216763 for $24 \mathrm{~h}$. Cell extracts were analyzed for p57 content by immunoblotting. The ratio between p57 and actin signal intensities is also shown. Further details for the densitometric analysis reported in panels (C) and (E) are described in Materials and Methods, Section 5.

Lithium is considered a prototypical inhibitor of GSK3 $\alpha / \beta$, a multifunctional kinase involved in many pathways that regulate a variety of biological processes. The best characterized is the TKR-(or PI3K)-AKT-GSK3-WNT/ $\beta$-catenin pathway. Particularly, $\beta$-catenin is a substrate of GSK3 $\beta$. The GSK3 $\beta$-dependent phosphorylation targets the protein for ubiquitination and subsequent proteasome degradation therefore contributing to its regulation [34]. In our model, Li treatment gives a dose-dependent increase of phosphoSer9/phosphoSer11-GSK3 (the inactive form of GSK3 $\beta$ ) levels and a more evident $\beta$-catenin accumulation (Figure 3C). This is in agreement with data found in the literature reporting a Li-dependent increase of the inhibitory $\mathrm{N}$-terminal phosphorylation of the enzyme, possibly by an autoregulation mechanism [34]. Therefore, we investigated the activity of SB216763, a selective inhibitor of GSK3, on p57, both at the mRNA and protein levels. While $25 \mu \mathrm{M}$ SB216763 exposure for $24 \mathrm{~h}$ strongly reduced CDKN1C gene transcription (Figure 3D), dose-dependent experiments $(5-25 \mu \mathrm{M})$ showed a modest (approximately 30\%) decrease of p57 protein (Figure 3E). These findings suggest that GSK3 inhibition might explain only in part Li activity on p57 cellular content. On the other hand, it has been reported that the Wnt/ $\beta$-catenin pathway downregulates $C D K N 1 C$ expression during midbrain dopaminergic neuron development, promoting cell cycle progression of neural precursor cells [35]. Thus, it is reasonable to hypothesize that $\mathrm{LiCl}$ upregulates $\beta$-catenin (Figure 3C) by GSK3-dependent and/or -independent mechanisms and that this event results in p57 downregulation.

\subsection{Role of $p 57$ Decrease in Li-Dependent DNA Damage Response}

As previously shown, Li determined a progressive dose-dependent increase of $\gamma \mathrm{H} 2 \mathrm{AX}$ and p53 that is associated to $\mathrm{p} 57$ reduction. Since $\mathrm{p} 57$ has been demonstrated to act as a positive effector in survival response under stress conditions, we hypothesized that p57 downregulation might play a role in Li-dependent DNA damage in SH-SY5Y cells. To confirm this hypothesis, we decided to handle p57 level (both increase and decrease) and investigate possible change of Li genotoxicity. Thus, SH-SY5Y cells were transfected with p57-pcDNA3.1 and then treated with $25 \mathrm{mM} \mathrm{Li}$. The data reported in the left panel of Figure 4A confirmed the transfection efficiency. More importantly, as shown in Figure 4A (center and right panels), p57 forced expression clearly restrained the Li-dependent build-up of $\gamma \mathrm{H} 2 \mathrm{AX}$, p53, and p21. 
A

p57 Transfection - - + +
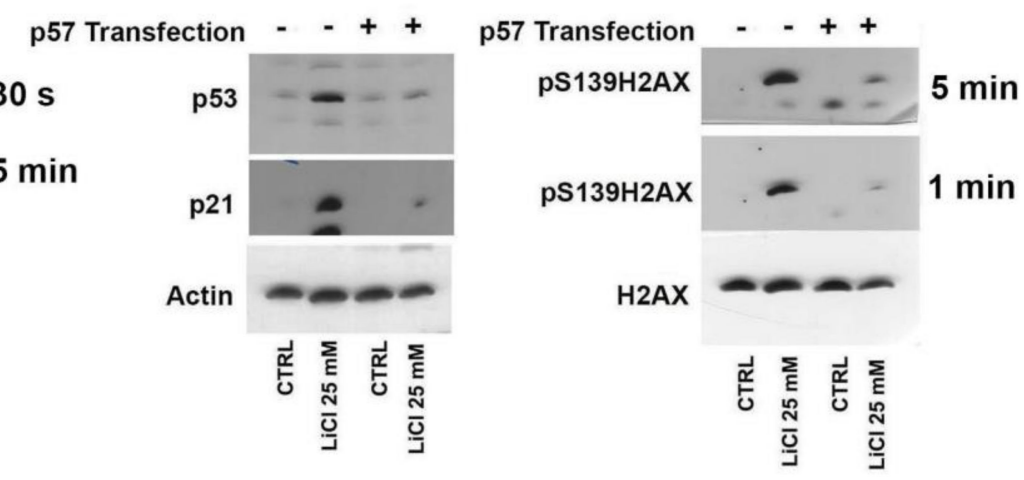

B

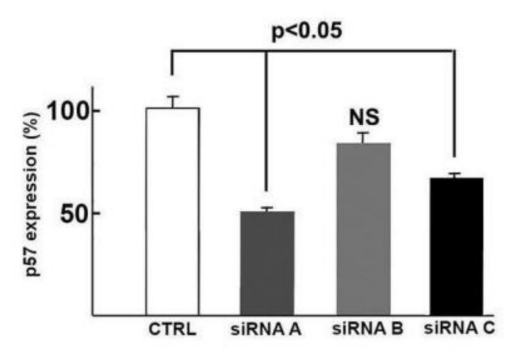

D

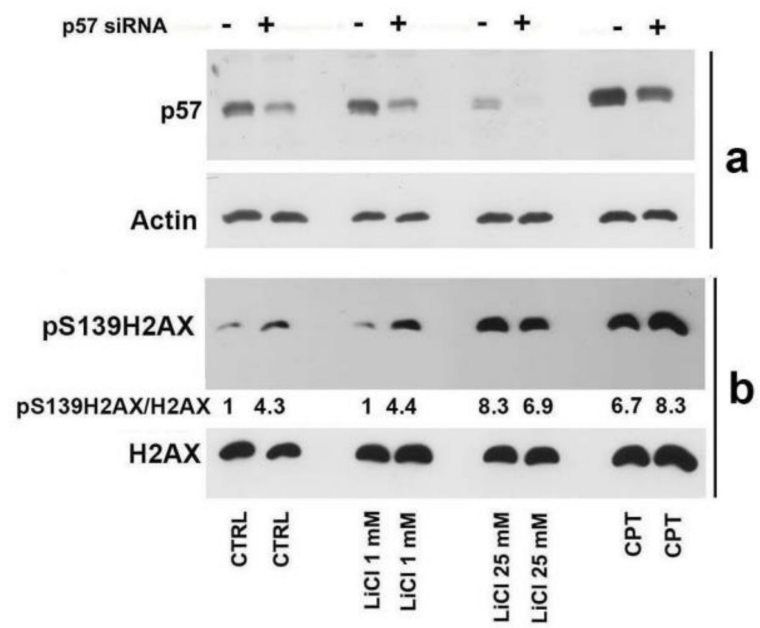

C

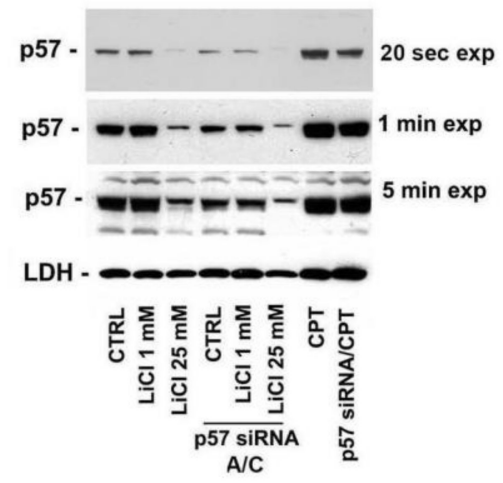

E

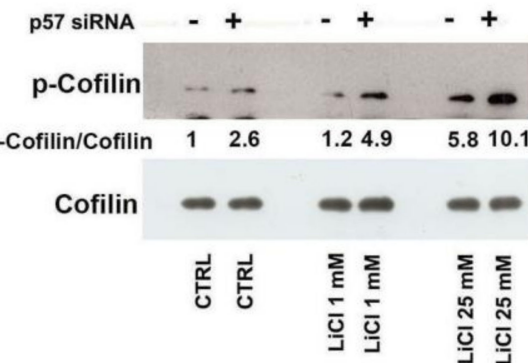


Figure 4. Importance of the decrease of p57 in lithium-dependent DNA damage. (A) SH-SY5Y cells were plated in multiple wells at equal density (50-60\% of confluency). After $24 \mathrm{~h}$, an equal number of cells were transfected with $300 \mathrm{ng}$ of a p57-encoding pcDNA3.1 plasmid or with a pcDNA3.1 empty vector; then, $8 \mathrm{~h}$ after transfection, each cell population was exposed to $25 \mathrm{mM} \mathrm{LiCl}$ or to $25 \mathrm{mM} \mathrm{NaCl}$ (CTRL) for $24 \mathrm{~h}$. Cells extracts were analyzed by immunoblotting for specific proteins, as reported (p57 on the left, p53 and p21 in the middle, pSer139/H2AX and total H2AX on the right). Two films at different exposure times ( $30 \mathrm{~s}$ and $5 \mathrm{~min}$ ) for p57 and for pSer139/H2AX (1 and $5 \mathrm{~min}$ ) are shown. (B) Three different siRNAs directed against CDKN1C (named siRNA A, B, and C) were transfected (at $100 \mathrm{nM}$ concentration) in SH-SY5Y cells (see Materials and Methods, Section 5). Forty-eight hours after transfection, cells were harvested, and total RNA was prepared. CDKN1C expression was evaluated by quantitative RT-PCR. The data shown are the mean of three experiments, and the standard deviation (T bar) is reported. (C) SH-SY5Y cells were first transfected with a mixture of anti-p57 siRNA A and siRNA C (siRNA A/C) for $48 \mathrm{~h}$ and thereafter exposed to $1 \mathrm{mM}$ and $25 \mathrm{mM} \mathrm{LiCl}$ for $24 \mathrm{~h}$; a specific control included cells incubated for $24 \mathrm{~h}$ with $25 \mathrm{mM} \mathrm{NaCl}$ after $48 \mathrm{~h}$ of transfection with a scramble siRNA. The transfected cells were also compared to SH-SY5Y cells treated with the two different Li concentrations ( $1 \mathrm{mM}$ and $25 \mathrm{mM}$ ) for $24 \mathrm{~h}$. In addition, SH-SY5Y cells were treated with $2 \mu \mathrm{M} \mathrm{CPT}$ (camptothecin) for $5 \mathrm{~h}$ after transfection (or not) with siRNAs. Then, equal amounts of proteins were analyzed for p57 content by immunoblotting. LDH was used as equal loading control. Three different exposure times are shown to highlight signal differences. (D) SH-SY5Y cells were treated with $\mathrm{NaCl}$ (CTRL) or with $\mathrm{LiCl}$ at two different concentrations in the presence or absence of the siRNA mixture. Moreover, cells were treated with $2 \mu \mathrm{M} \mathrm{CPT}$. After $24 \mathrm{~h}$, cell extracts were prepared and analyzed. In (a), p57 and actin levels were investigated while, in (b), $\gamma \mathrm{H} 2 \mathrm{AX}$ (pS139H2AX) and H2AX were studied. The ratios between p57/actin and $\gamma \mathrm{H} 2 \mathrm{AX} / \mathrm{H} 2 \mathrm{AX}$ were also reported. (E) The samples in (D) were analyzed for phosphoserine3-cofilin and cofilin content. The ratio between phosphocofilin and cofilin signal intensities is also shown. Details of the densitometry analysis are in Materials and Methods, Section 5.

Conversely, p57 cellular content was negatively regulated by a Li-independent approach, i.e., small interfering RNA (siRNA) treatment and, thereafter, the effect on DNA integrity of the gene silencing, in combination (or not) with Li treatment, was evaluated. The efficiency of different p57 siRNAs (here defined as siRNA-A, -B, and -C) was preliminarily investigated by RT-PCR. Two out of three siRNAs tested (i.e., A and C) reduced p57 transcript levels by roughly 50\% compared to control cells treated with scramble siRNA (Figure 4B). Thus, a siRNA (A plus C) mixture was used to downregulate p57 protein levels. As showed in Figure 4C, siRNA's addition markedly reduced p57 cellular content. This reduction was similar in the control cells and in cells treated with $1 \mathrm{mM} \mathrm{Li}$, while in cells treated with $25 \mathrm{mM} \mathrm{Li}$, siRNA transfection further enhanced the negative Li activity on p57. Different time exposure of immunoblot are shown in Figure 4C, allowing for a clear detection of the siRNA treatment's effect. In the experiment shown in Figure 4C, SH-SY5Y cells were also treated with $2 \mu \mathrm{M}$ camptothecin (CPT) for $5 \mathrm{~h}$ as a positive control. Camptothecin is an antineoplastic agent that blocks the activity of DNA topoisomerase thus causing high levels of DSBs [36]. Interestingly, CPT remarkably increased p57 cellular content, and the treatment with siRNA was still capable of reducing the enhancement of p57 levels.

Subsequently, we investigated the entity of DSBs in siRNA-treated cells by evaluating $\gamma \mathrm{H} 2 \mathrm{AX}$ levels. As reported in Figure 4D, p57 downregulation increased the signal of the DNA alteration marker. The effect was similarly observed in control cells and in cells treated with low Li concentration $(1 \mathrm{mM})$. The ratio between phosphorylated and total histone was comparable, strongly suggesting that the p57 protein level should play a role in DSB. At $25 \mathrm{mM} \mathrm{Li}$, p57 siRNA treatment did not increase the effect of the ion, probably since Li by itself strongly reduces p57. On the other hand, only a partial p57 silencing increased CPT activity in inducing DSB, confirming the general view that the expression of p57 promoted by genotoxic agents might be important for DNA integrity under stress conditions. We also evaluated cofilin phosphorylation, since, as previously reported in Figure 1F, the post-synthetic modification increased after Li treatment. Figure 4E shows that siRNA treatment (and p57 decrease) 
enhances phospho-cofilin levels, exerting an additive effect on Li treatment. The activity of siRNA exposure was observed in all the conditions analyzed. These data support the hypothesis that the downregulation of p57 might play a role in augmenting Li-dependent effects on actin dynamics in SH-SY5Y cells, an event that might be associated to cell motility, induction of apoptosis and also to DNA damage response.

\section{Discussion}

Here we report the unprecedented observation that Li downregulates, in neuroblastoma cells, the p57 level by reducing $C D K N 1 C$ transcription and also affects its post-translational modifications. p57 is a multifunctional protein involved in the control of growth, differentiation, gene expression, cytoskeletal organization, and apoptosis $[24,33,37]$. Recent pieces of evidence suggest that p57 plays a vital role in the maintenance of cellular homeostasis under stress conditions including those correlated with genotoxic response and activation of programmed cell death [27]. Several of these activities are executed independently of its CDK inhibitory functions and might be related to the plasticity of the protein [38]. Thus, Li's effect on p57 content might be relevant in the complex molecular activity of the ion.

In our cell model, Li induced DNA damage, specifically DSBs, as directly demonstrated by the enhanced phosphorylation of H2AX histone. In addition, Li reduced cell cycle progression to allow DNA damage repair (possibly through p53 and p21 Cip1 accumulation), while over prolonged time, it may induce apoptosis (Figure 1D). Contemporaneously, Li reduced p57 cellular content. So far, p57 has never been associated to Li's effects on neural cells, despite the reported relevance of p57 in the nervous system and, particularly, in midbrain dopamine cells [35]. The mechanisms by which Li affected p57 cellular content involved downregulation of CDKN1C expression. Moreover, a clear alteration of p57. phosphorylation occurred in Li-treated cells, suggesting that post-translational modifications might also play a role in the downregulation of the protein or in modifying its activity.

With GSK3 $\beta$ being one of the best known $\mathrm{LiCl}$ target, we hypothesized that the inhibition of the kinase activity might be responsible for the transcriptional reduction of CDKN1C expression and/or changes in the protein phosphorylation. GSK3 $\beta$ is considered a master regulator gene of neural progenitor cells [39], and in several cell populations it regulates numerous pathways including those activated by Wnt receptors through the modulation of $\beta$-catenin turnover [40]. $\beta$-Catenin is a dual function protein, playing roles in cell adhesion and gene transcription, and its GSK3 $\beta$-mediated phosphorylation induces the destabilization of the protein [41]. It has been reported that $\mathrm{Wnt} / \beta$-catenin pathway reduces $C D K N 1 C$ expression during midbrain dopaminergic neuron development, promoting cell cycle progression of neural precursor cells [35]. Thus, since an increase of $\beta$-catenin protein levels following treatment with $\mathrm{LiCl}$ were detected, we hypothesized that the downregulation of p57 by $\mathrm{Li}$ might be due, at least in part, to the fact of GSK3 $\beta$ inhibition and the subsequent $\beta$-catenin activation. To evaluate this hypothesis, we treated SH-SY5Y cells with SB216763, a specific GSK3 inhibitor and observed a clear reduction of the p57 transcript. On the other hand, the analysis of p57 protein levels after SB216763 treatment did not show a remarkable decrease of the protein, suggesting that other mechanisms, probably not GSK3 $\beta$ related, are involved in Li-dependent p57 downregulation. An intriguing and alternative possibility relies on the reported capability of ROS to activate, independently of GSK3 $\beta$, the Wnt $/ \beta$-catenin pathway [42] which, in turn, might affect $C D K N 1 C$ expression. However, further investigations are needed to shed light on this possible mechanism.

A p57 increase has been suggested as a mechanism of defense against stress conditions [25-28]. Therefore, we hypothesized that the Li-dependent decrease of p 57 might be involved in or might enhance Li-induced DNA damage. To evaluate whether p57 downregulation plays a role in Li-associated accumulation of DSBs, we increased p57 intracellular levels by transfecting the p57 expression vector. As reported in Figure 4A, p57 overexpression clearly reduced the upregulation of the major markers of DNA damage induced by $\mathrm{Li}$ treatment. The finding represents compelling evidence that the Li-dependent p57's decrease being involved in the DNA damage induced by the ion. 
To further strengthen this hypothesis, we performed CDKN1C knockdown by specific siRNA (Figure $4 \mathrm{~B}, \mathrm{C}$ ) and analyzed the changes of the phosphorylation state of $\mathrm{H} 2 \mathrm{AX}$ and cofilin, two important events associated to DSB and actin cytoskeletal remodeling, respectively. The major result of these experiments was the observation that, in control cells or in cells treated with $1 \mathrm{mM} \mathrm{Li}$ (a concentration which neither affects $\mathrm{p} 57$ levels nor causes $\mathrm{H} 2 \mathrm{AX}$ and cofilin phosphorylation), the reduction of $\mathrm{p} 57$ by siRNA increased the post-translational modifications of both proteins (Figure $4 \mathrm{D}, \mathrm{E}$ ). As matter of fact, the importance of p57 in DSB response was also confirmed by the observation that the treatment with CPT, a well-known inducer of DSBs, strongly upregulated p57 (Figure 4C) and that CDKN1C silencing in CPT-treated cells further increased $\gamma \mathrm{H} 2 \mathrm{AX}$ levels (Figure $4 \mathrm{D}$ ).

It must be stressed that the CPT mechanism of action (i.e., inhibition of topoisomerase) appeared to be distinct from that of Li. The CPT-dependent increase in p57 hints that p57 upregulation follows DNA damage and is involved in the cellular response to DSBs. The precise role of p57 in the DNA damage response appears to be, although evidenced in this and other studies, still unclear and warrants further investigations.

In conclusion, our study furnishes novel information on Li molecular effects by demonstrating that the ion decreases the level of p57. This unreported activity appears to augment the DNA damaging activity of the Li. Moreover, and probably more importantly, our findings suggest the unexpected conclusion that p57 cellular levels play a general role in the modulation of DSBs. Given the relevance of DSBs and DSB responses in a plethora of biological and clinical conditions, including malignant transformation and chemotherapy efficacy, further investigations are warranted to clarify the precise function of p57 in DNA stability. Finally, the unanticipated interplay among p57 content, p53 level, and H2AX phosphorylation needs to be mechanistically investigated.

\section{Critical Assessment on Lithium-Employed Concentrations and Dosages}

For more than 60 years, lithium has represented a preferred treatment for bipolar and mood disorders. However, lithium is a drug with a narrow therapeutic index, namely, a drug with little difference between the therapeutic and toxic doses. As a matter of fact, lithium salt is still the primary therapy for bipolar disorder but, at the same time, the nervous system is the primary target of lithium toxicity. The dosage generally employed corresponds to a serum concentration of about $0.8-1.2 \mathrm{mM}$ [43]. This value is clearly different and lower compared to the concentrations employed in this study as well as in a large number of reports on lithium cellular effects reported in literature [43]. Thus, this report might be mainly considered as an investigation evaluating the mechanisms of lithium effects at toxic concentrations. However, some additional aspects should be taken into consideration. First, the reported experiments demonstrate that lithium, at 5-10 mM, is able, after $24 \mathrm{~h}$ treatment, to induce a clear $\gamma \mathrm{H} 2 \mathrm{AX}$ increase and p57 decrease (Figure 2). Nevertheless, there are no data regarding lithium effects (during a chronic therapeutic treatment) on the cellular content of p57, a molecule that plays important roles in the physiology/pathology of neuronal cells. Thus, a potential effect on p57 at prolonged lithium therapeutic dosage might not be ruled out. Second, our study employs concentrations of the drug that have been frequently used in investigations evaluating lithium as an anti-proliferative agent in the treatment of numerous cancers, including glioma [44], colorectal cancer [45], medulloblastoma [46], hepatocellular carcinoma [47], and other tumors [48]. Although the dosages employed in these studies were clearly toxic, the development of delivery strategies specifically targeting cancer cells is conceivable. Finally, this investigation points to the downregulation of p57 (obtainable through molecular approaches independent of Li treatment) as a mechanism for enhancing the effect of antitumoral DNA-damaging drugs (like camptothecin, topotecan, irinotecan, doxorubicin, etc.). Under this view, our findings might be useful in the development of novel anticancer approaches based on the identification of new targets for potentiating the activity of already clinically employed drugs or for reducing their doses and negative side effects. 


\section{Materials and Methods}

\subsection{Cell Culture and Treatments}

Human neuroblastoma SH-SY5Y and LAN-5 cell lines (ATCC, Manassas, VA, USA) were cultured in RPMI (Gibco, Thermo Fisher Scientific, Waltham, MA, USA), supplemented with 10\% fetal bovine serum (FBS, Invitrogen, Thermo Fisher Scientific), $100 \mathrm{U} / \mathrm{mL}$ benzylpenicillin, $100 \mathrm{mg} / \mathrm{L}$ streptomycin (Gibco), and cultured in a humidified incubator with $5 \% \mathrm{CO}_{2}$ at $37^{\circ} \mathrm{C}$. To investigate $\mathrm{Li}$ effects, $\mathrm{LiCl}$ (Sigma, St. Louis, MO, USA) was added to the culture medium for increasing times and doses; $\mathrm{NaCl}$ (Sigma) was used in the control treatment. The effect on the growth rate was evaluated by direct cell counting after $24 \mathrm{~h}$ incubation at different concentrations of $\mathrm{LiCl}$ (from $1 \mathrm{mM}$ to $25 \mathrm{mM}$ ) and after different durations of incubation with $25 \mathrm{mM} \mathrm{LiCl}$. Twenty-five $\mathrm{mM} \mathrm{NaCl}$ was used as control in all experiments where $\mathrm{LiCl}$ effects were exploited. The data are shown as the mean of three independent experiments, and the standard deviation (T bar) is reported. The GSK3 $\alpha / \beta$ inhibitor SB216763 (Sigma) was solubilized in DMSO (Sigma) and used at increasing concentrations in the culture medium from $5 \mu \mathrm{M}$ to $25 \mu \mathrm{M}$. Control cells were in this case exposed to the maximum DMSO concentration reached. Two $\mu \mathrm{M}$ CPT (Sigma) treatment was used as positive control of DSB induction. All the other reagents were of the highest purity grade commercially available.

\subsection{Analysis of Cell Cycle Distribution}

The cell layers under investigation were harvested and centrifuged at $800 \times g$ for $5 \mathrm{~min}$. The cell pellets were washed in phosphate buffered saline (PBS) and then permeabilized with a hypotonic solution containing $10 \mathrm{mM}$ sodium citrate, $2 \mathrm{mM}$ propidium iodide, $20 \mathrm{mM}$ DNase-free RNase (Sigma), and $1 \%$ NP-40. The cells were incubated at room temperature for $30 \mathrm{~min}$ in the dark and then analyzed using FACScalibur (Becton Dickinson, CA, USA). Cell cycle distribution was calculated from 30.000-40.000 events with ModFit LTTM software (Becton Dickinson) [49].

\subsection{Real-Time RT-PCR Analyses}

Total RNA from SH-SY5Y was extracted using TRIzol reagent (Invitrogen) [50,51]. Two micrograms of total RNA were reverse transcribed into complementary DNA. The p57 mRNA levels were quantified by real-time RT-PCR (RT-qPCR) using QuantiTect Primer Assays, cod. Hs_CDKN1C_1_SG cat. Num. QT00018018 (QIAGEN, Hilden, Germany) and normalized with 18S (QIAGEN) expression used as an internal control. Sequences of the used Primers are: 185 Fw, 5'-AAACGGCTACCACATCCAAG-3'; Rev, $5^{\prime}$-CCTCCAATGGATCCTCGTTA-3'. The amplification was performed in an ABI PRISM®7900 Sequence Detection System (Applied Biosystems, Monza, Italy) according to protocols supplied. Relative quantification was executed by $\Delta \Delta \mathrm{Ct}$ methods [52] and obtained from, at least, three independent experiments. Data with a significance of $p<0.05$ were accepted.

\subsection{Cell Extracts Preparation and Mono- and Two-Dimensional Western Blotting Analyses}

For whole cell extract preparation, cells were lysed in ice-cold RIPA buffer containing $50 \mathrm{mmol} / \mathrm{L}$ Tris- $\mathrm{HCl}, \mathrm{pH} 8.0,150 \mathrm{mmol} / \mathrm{L} \mathrm{NaCl}, 1 \% \mathrm{NP}-40,1 \%$ sodium deoxycholate, $0.1 \%$ sodium dodecylsulfate, $0.1 \mathrm{mmol} / \mathrm{L}$ dithiothreitol, $0.05 \mathrm{mmol} / \mathrm{L}$ phenylmethyl-sulfonylfluoride, $0.002 \mathrm{mg} / \mathrm{mL}$ aprotinin, $0.002 \mathrm{mg} / \mathrm{mL}$ leupeptin, $1 \mathrm{mmol} / \mathrm{L}$ sodium orthovanadate, $40 \mathrm{mM}$ sodium fluoride, and $1 \mathrm{mM}$ sodium pyrophosphate decahydrate. Nuclear and cytosolic fractionation was performed as follows. Briefly, harvested cells were washed with ice-cold PBS, resuspended in ice-cold hypotonic buffer (10 mM HEPES, pH 7.9, $1.5 \mathrm{mM} \mathrm{MgCl}$ and $10 \mathrm{mM} \mathrm{KCl}$ enriched with protease and phosphatase inhibitors) and incubated on ice for twenty minutes, allowing them to swell. Then, IGEPAL CA-630 solution (Sigma) was added to $0.6 \%$ final concentration and, after $15 \mathrm{~s}$ incubation, cells were centrifuged at $10,000 \times g$ for $2 \mathrm{~min}$. The supernatants, containing the cytosolic fraction, were transferred into new tubes. The pellet nuclei were then resuspended in RIPA buffer and incubated for 30 minutes on ice. After 15 min of centrifugation at $16,000 \times g$, the supernatants (the nuclear extracts) were recovered in 
fresh tubes. The BioRad assay reagent (Bio-Rad, Hercules, CA, USA) was used to quantify the protein concentration. The nuclear and cytoplasmic extracts obtained were tested for cross-contamination through immunoblotting for $\mathrm{HDAC} 1$ and $\mathrm{LDH} \alpha$, respectively.

Mono-dimensional SDS-PAGE (10-15\% different acrylamide concentrations) was used to load and separate proteins. Upon electrophoresis, proteins were transferred onto nitrocellulose (Millipore, Burlington, MA, USA) and the membranes incubated overnight with appropriate primary antibodies. Then, HRP-conjugated secondary antibodies (Santa Cruz Biotechnology, Inc, Heidelberg, Germany) were applied to bind to and visualize primary antibodies [49]. Bidimensional analysis was performed as reported previously [53]. The following primary antibodies were employed: anti-p57 (mouse monoclonal), anti-actin (rabbit polyclonal), anti-p53 (mouse monoclonal), anti-phosphoSer3 cofilin (mouse monoclonal) and anti-cofilin (rabbit polyclonal), anti- $\gamma \mathrm{H} 2 \mathrm{AX}$ (mouse monoclonal), anti-PARP1 (mouse monoclonal) and anti-GSK3 $\alpha / \beta$ (mouse monoclonal), anti-HDAC1 (rabbit polyclonal), all purchased from Santa Cruz Biotechnology; anti-p21 ${ }^{\mathrm{Cip} 1}$ (mouse monoclonal) and anti phospho-GSK-3 $\alpha / \beta$ (Ser21/9) (rabbit monoclonal) from Cell Signaling Technology (Leiden, The Netherlands); anti-p27 ${ }^{\text {Kip1 }}$ (mouse monoclonal), purchased from BD Transduction Laboratories (Franklin Lakes, NJ, USA). ImageJ software was used for evaluating the intensity of immunoblotting signals. The intensity of actin or other proteins was used as the control of the equal loading of the protein amount, whereas for the analysis of the phosphorylation's variation, the intensity of the corresponding total protein signal was used as the control and to establish the changes in phosphorylation degree. The variations of a specific protein were calculated as the ratio of the intensity of the signal of interest and the intensity of the loading control. Accordingly, the fold changes of the investigated protein in the different experimental conditions were calculated dividing each ratio with the ratio of the control (considered as 1). Therefore, the value for the control was 1 and samples with a positive variation reported a number greater than 1 , whereas samples with a negative variation reported a number less than 1.

\subsection{Plasmid Transfection and Gene Silencing Using Small Interfering RNA (siRNA)}

The coding sequence of p57 was cloned in pcDNA3.1 plasmid. The SH-SY5Y cells, at $60-70 \%$ confluence, were transfected with the plasmid using Lipofectamine3000 (Invitrogen) according to the manufacturer's instructions. Control cells were transfected with the empty plasmid. After $8 \mathrm{~h}$ of transfection, cells were added with $25 \mathrm{mM} \mathrm{LiCl}$ for $24 \mathrm{~h}$ or with $25 \mathrm{mM} \mathrm{NaCl}$ as CTRL. Thereafter, SH-SY5Y cells were collected and processed for subsequent analyses. The p57 siRNA and scramble siRNA were provided by Origene (OriGene Technologies $\mathrm{GmbH}$, Herford, Germany). Cells at $60 \%$ confluence were transfected with $100 \mathrm{nmol} / \mathrm{L}$ siRNA using Lipofectamine3000 (Invitrogen) according to the manufacturer's instructions. After $48 \mathrm{~h}$ of transfection, $\mathrm{LiCl}$, at $1 \mathrm{mM}$ and $25 \mathrm{mM}$ concentrations, was added (or not) to media for further $24 \mathrm{~h}$. Thereafter, cells were processed for subsequent analyses. The CDKN1C mRNA quantification and p57 immunoblotting were used to verify the efficiency of CDKN1C silencing.

\subsection{Evaluation of Intracellular ROS Level and DNA Damage Analysis}

The ROS quantification was performed using $2^{\prime}, 7^{\prime}$-dichlorofluorescein diacetate (DCF-DA, Sigma) as previous reported by Borriello et al. [49]. In these experiments, the treatment with $1 \mathrm{mM}$ tert-butyl hydroperoxide (TBH) was used as the positive control [49]. To evaluate the effect of Li-mediated oxidative stress on the proliferation rate, SH-SY5Y cells were seeded the day before in 6 well culture plates at low density and treated for $24 \mathrm{~h}$ with $25 \mathrm{mM} \mathrm{LiCl}$ in combination or not with $150 \mu \mathrm{M}$ NAC (Sigma). The NAC was added $2 \mathrm{~h}$ before treating SH-SY5Y cells with $\mathrm{LiCl}$ for $24 \mathrm{~h}$. Then, the cells were counted and the average of the three experimental replicates was calculated. For DSB evaluation, Western blotting of $\gamma \mathrm{H} 2 \mathrm{AX}$ levels was performed. Five hour incubation with $2 \mu \mathrm{M} \mathrm{CPT}$ was used as the positive control for the DSB. 


\subsection{Statistical Analysis}

Experimental data are presented as mean values \pm standard deviation. Comparison between groups of determination was performed using Sample $t$-test. A value of $p<0.05$ was considered statistically significant.

Author Contributions: Conceptualization, A.B., F.D.R., E.S. and D.B; Investigation, E.S., D.B., C.B., A.A. and F.V.; Writing, review, and editing A.B., F.D.R. and E.S. All authors have read and agreed to the published version of manuscript.

Funding: This study was supported by grants from the Associazione Italiana per la Ricerca sul Cancro (AIRC) (no. 11653 to F.D.R.), Programma VALERE: Vanvitelli per la Ricerca (for D.B. salary), PON Ricerca e Innovazione 2014-2020, and AIM Attrazione e Mobilità Internazionale del MIUR (for E.S. salary).

Conflicts of Interest: The authors declare no conflict of interest.

\section{References}

1. Grof, P.; Müller-Oerlinghausen, B. A Critical Appraisal of Lithium's Efficacy and Effectiveness: the Last 60 Years. Bipolar Disord. 2009, 11, 10-19. [CrossRef] [PubMed]

2. Curran, G.; Ravindran, A. Lithium for Bipolar Disorder: a Review of the Recent Literature. Expert Rev. Neurother. 2014, 14, 1079-1098. [CrossRef] [PubMed]

3. Yatham, L.N.; Kennedy, S.H.; Parikh, S.V.; Schaffer, A.; Beaulieu, S.; Alda, M.; O'Donovan, C.; Macqueen, G.; McIntyre, R.S.; Sharma, V. Canadian Network for Mood and Anxiety Treatments (CANMAT) and International Society for Bipolar Disorders (ISBD) Collaborative Update of CANMAT Guidelines for the Management of Patients with Bipolar Disorder: Update 2013. Bipolar Disord. 2013, 15, 1-44. [CrossRef] [PubMed]

4. Vadnal, R.; Parthasarathy, R. Myo-inositol Monophosphatase: Diverse Effects of Lithium, Carbamazepine, and Valproate. Neuropsychopharmacology 1995, 12, 277-285. [CrossRef]

5. Risby, E.D.; Hsiao, J.K.; Manji, H.K.; Bitran, J.; Moses, F.; Zhou, D.F.; Potter, W.Z. The Mechanisms of Action of Lithium. II. Effects on Adenylate Cyclase Activity and Beta-Adrenergic Receptor Binding in Normal Subjects. Arch Gen. Psychiatry 1991, 48, 513-524. [CrossRef] [PubMed]

6. Manji, H.K.; Bersudsky, Y.; Chen, G.; Belmaker, R.H.; Potter, W.Z. Modulation of Protein Kinase C Isozymes and Substrates by Lithium: the Role of Myo-Inositol. Neuropsychopharmacology 1996, 15, 370-381. [CrossRef]

7. Chalecka-Franaszek, E.; Chuang, D.M. Lithium Activates the Serine/Threonine Kinase Akt-1 and Suppresses Glutamate-induced Inhibition of Akt-1 Activity in Neurons. Proc. Natl. Acad. Sci. USA 1999, 96, 8745-8750. [CrossRef]

8. Meffre, D.; Grenier, J.; Bernard, S.; Courtin, F.; Dudev, T.; Shackleford, G.; Jafarian-Tehrani, M.; Massaad, C. Wnt and Lithium: A Common Destiny in the Therapy of Nervous System Pathologies? Cell. Mol. Life Sci. 2014, 71, 1123-1148. [CrossRef]

9. Jope, R.S. Lithium and GSK-3: One Inhibitor, Two Inhibitory Actions, Multiple Outcomes. Trends Pharmacol. Sci. 2003, 24, 441-443. [CrossRef]

10. Beurel, E.; Grieco, S.F.; Jope, R.S. Glycogen Synthase Kinase-3 (GSK3): Regulation, Actions, and Diseases. Pharmacol. Ther. 2015, 148, 114-131. [CrossRef]

11. Qing, Z.; Yang, J.; Han, S.; Liu, J.; Holzbeierlein, J.; Thrasher, J.B.; Li, B. Suppression of Glycogen Synthase Kinase 3 Activity Reduces Tumor Growth of Prostate Cancer in Vivo. Prostate 2011, 71, 835-845. [CrossRef]

12. Duffy, D.J.; Krstic, A.; Schwarzl, D.; Higgins, D.G.; Kolch, W. GSK3 Inhibitors Regulate MYCN mRNA Levels and Reduce Neuroblastoma Cell Viability through Multiple Mechanisms, Including p53 and Wnt Signaling. Mol. Cancer Ther. 2014, 13, 454-467. [CrossRef] [PubMed]

13. Li, H.; Huang, K.; Liu, X.; Liu, J.; Lu, X.; Tao, K.; Wang, G.; Wang, J. Lithium Chloride Suppresses Colorectal Cancer Cell Survival and Proliferation through ROS/GSK-3ß/NF-кB Signaling Pathway. Oxid. Med. Cell. Longev. 2014, 2014, 241864. [CrossRef] [PubMed]

14. Forlenza, O.V.; De-Paula, V.J.R.; Diniz, B.S.O. Neuroprotective Effects of Lithium: Implications for the Treatment of Alzheimer's Disease and Related Neurodegenerative Disorders. ACS Chem. Neurosci. 2014, 5, 443-450. [CrossRef] [PubMed] 
15. Guidotti, S.; Minguzzi, M.; Platano, D.; Cattini, L.; Trisolino, G.; Mariani, E.; Borzì, R.M. Lithium Chloride Dependent Glycogen Synthase Kinase 3 Inactivation Links Oxidative DNA Damage, Hypertrophy and Senescence in Human Articular Chondrocytes and Reproduces Chondrocyte Phenotype of Obese Osteoarthritis Patients. PLoS ONE 2015, 10, e0143865. [CrossRef] [PubMed]

16. Yang, E.S.; Wang, H.; Jiang, G.; Nowsheen, S.; Fu, A.; Hallahan, D.E.; Xia, F. Lithium-mediated Protection of Hippocampal Cells Involves Enhancement of DNA-PK-Dependent Repair in Mice. J. Clin. Invest. 2009, 119, 1124-1135. [CrossRef]

17. McKinnon, P.J. Maintaining Genome Stability in the Nervous System. Nat. Neurosci. 2013, 16, $1523-1529$. [CrossRef]

18. Jacoby, A.S.; Vinberg, M.; Poulsen, H.E.; Kessing, L.V.; Munkholm, K. Increased DNA and RNA Damage by Oxidation in Patients with Bipolar I Disorder. Transl. Psychiatry 2016, 6, e867. [CrossRef]

19. McKinnon, P.J. Genome Integrity and Disease Prevention in the Nervous System. Genes Dev. 2017, 31, 1180-1194. [CrossRef]

20. Lovejoy, C.A.; Cortez, D. Common Mechanisms of PIKK Regulation. DNA Repair 2009, 8, 1004-1008. [CrossRef]

21. Paull, T.T.; Rogakou, E.P.; Yamazaki, V.; Kirchgessner, C.U.; Gellert, M.; Bonner, W.M. A Critical Role for Histone H2AX in Recruitment of Repair Factors to Nuclear Foci After DNA Damage. Curr. Biol. 2000, 10, 886-895. [CrossRef]

22. Yang, J.; Yu, Y.; Hamrick, H.E.; Duerksen-Hughes, P.J. ATM, ATR and DNA-PK: Initiators of the Cellular Genotoxic Stress Responses. Carcinogenesis 2003, 24, 1571-1580. [CrossRef]

23. Macleod, K.F.; Sherry, N.; Hannon, G.; Beach, D.; Tokino, T.; Kinzler, K.; Vogelstein, B.; Jacks, T. p53-dependent and Independent Expression of p21 During Cell Growth, Differentiation and DNA Damage. Gen. Dev. 1995, 9, 935-944. [CrossRef] [PubMed]

24. Besson, A.; Dowdy, S.F.; Roberts, J.M. CDK Inhibitors: Cell Cycle Regulators and Beyond. Dev. Cell 2008, 14, 159-169. [CrossRef] [PubMed]

25. Yan, Y.; Frisén, J.; Lee, M.H.; Massagué, J.; Barbacid, M. Ablation of the CDK Inhibitor p57Kip2 Results in Increased Apoptosis and Delayed Differentiation During Mouse Development. Genes Dev. 1997, 11, 973-983. [CrossRef]

26. Joaquin, M.; Gubern, A.; González-Nuñez, D.; Josué Ruiz, E.; Ferreiro, I.; de Nadal, E.; Nebreda, A.R.; Posas, F. The p57 CDKi Integrates Stress Signals Into Cell-Cycle Progression to Promote Cell Survival Upon Stress. EMBO J. 2012, 31, 2952-2964. [CrossRef]

27. Chang, T.S.; Kim, M.J.; Ryoo, K.; Park, J.; Eom, S.J.; Shim, J.; Nakayama, K.I.; Nakayama, K.; Tomita, M.; Takahashi, K.; et al. p57KIP2 Modulates Stress-Activated Signaling by Inhibiting c-Jun NH2-Terminal Kinase/Stress-Activated Protein Kinase. J. Biol. Chem. 2003, 28, 278-48092. [CrossRef]

28. Rossi, M.N.; Antonangeli, F. Cellular Response upon Stress: p57 Contribution to the Final Outcome. Mediators Inflamm. 2015, 259325. [CrossRef]

29. Jia, H.; Cong, Q.; Chua, J.F.; Liu, H.; Xia, X.; Zhang, X.; Lin, J.; Habib, S.L.; Ao, J.; Zuo, Q.; et al. p57Kip2 is an Unrecognized DNA Damage Response Effector Molecule that Functions in Tumor Suppression and Chemoresistance. Oncogene 2015, 34, 3568-3581. [CrossRef]

30. Cassimere, E.K.; Mauvais, C.; Denicourt, C. p27 ${ }^{\text {Kip1 } 1}$ Is Required to Mediate a G1 Cell Cycle Arrest Downstream of ATM following Genotoxic Stress. PLoS ONE 2016, 11, e0162806. [CrossRef]

31. Vlachos, P.; Nyman, U.; Hajji, N.; Joseph, B. The Cell Cycle Inhibitor p57(Kip2) Promotes Cell Death via the Mitochondrial Apoptotic Pathway. Cell Death Differ. 2007, 14, 1497-1507. [CrossRef]

32. Stampone, E.; Caldarelli, I.; Zullo, A.; Bencivenga, D.; Mancini, F.P.; Della Ragione, F.; Borriello, A. Genetic and Epigenetic Control of CDKN1C Expression: Importance in Cell Commitment and Differentiation, Tissue Homeostasis and Human Diseases. Int. J. Mol. Sci. 2018, 19, 1055. [CrossRef]

33. Guo, H.; Tian, T.; Nan, K.; Wang, W. p57: A Multifunctional Protein in Cancer. Int. J. Oncol. 2010, 36, 1321-1329. [CrossRef] [PubMed]

34. Zhang, F.; Phiel, C.J.; Spece, L.; Gurvich, N.; Klein, P.S. Inhibitory Phosphorylation of Glycogen Synthase Kinase-3 (GSK-3) in Response to Lithium. Evidence for autoregulation of GSK-3. J. Biol. Chem. 2003, 278, 33067-33077. [CrossRef]

35. Castelo-Branco, G.; Wagner, J.; Rodriguez, F.J.; Kele, J.; Sousa, K.; Rawal, N.; Pasolli, H.A.; Fuchs, E.; Kitajewski, J.; Arenas, E. Differential Regulation of Midbrain Dopaminergic Neuron Development by Wnt-1, Wnt-3a, and Wnt-5a. Proc. Natl. Acad. Sci. USA 2003, 100, 12747-12752. [CrossRef] 
36. Ferrara, L.; Kmiec, E.B. Camptothecin Enhances the Frequency of Oligonucleotide-Directed Gene Repair in Mammalian Cells by Inducing DNA Damage and Activating Homologous Recombination. Nucl. Acids Res. 2004, 32, 5239-5248. [CrossRef]

37. Duquesnes, N.; Callot, C.; Jeannot, P.; Daburon, V.; Nakayama, K.I.; Manenti, S.; Davy, A.; Besson, A. p57(Kip2) Knock-In Mouse Reveals CDK-Independent Contribution in the Development of Beckwith-Wiedemann Syndrome. J. Pathol. 2016, 239, 250-261. [CrossRef]

38. Borriello, A.; Caldarelli, I.; Bencivenga, D.; Criscuolo, M.; Cucciolla, V.; Tramontano, A.; Oliva, A.; Perrotta, S.; Della Ragione, F. p57(Kip2) and Cancer: Time for a Critical Appraisal. Mol. Cancer Res. 2011, 9, 1269-1284. [CrossRef]

39. Kim, W.Y.; Wang, X.; Wu, Y.; Doble, B.W.; Patel, S.; Woodgett, J.R.; Snider, W.D. GSK-3 is a Master Regulator of Neural Progenitor Homeostasis. Nat. Neurosci. 2009, 12, 1390-1397. [CrossRef]

40. Wu, D.; Pan, W. GSK3: A Multifaceted Kinase in Wnt Signaling. Trends Biochem. Sci. 2010, 35, 161-168. [CrossRef]

41. Liu, C.; Li, Y.; Semenov, M.; Han, C.; Baeg, G.H.; Tan, Y.; Zhang, Z.; Lin, X.; He, X. Control of Beta-Catenin Phosphorylation/Degradation by a Dual-Kinase Mechanism. Cell 2002, 108, 837-847. [CrossRef]

42. Gilardini Montani, M.S.; Granato, M.; Cuomo, L.; Valia, S.; Di Renzo, L.; D’Orazi, G.; Faggioni, A.; Cirone, M. High glucose and hyperglycemic sera from type 2 diabetic patients impair DC differentiation by inducing ROS and activating Wnt/ $\beta$-catenin and p38 MAPK. Biochim. Biophys. Acta 2016, 1862, 805-813. [CrossRef] [PubMed]

43. Nolen, W.A.; Licht, R.W.; Young, A.H.; Malhi, G.S.; Tohen, M.; Vieta, E.; Kupka, R.W.; Zarate, C.; Nielsen, R.E.; Baldessarini, R.J.; et al. What is the Optimal Serum Level for Lithium in the Maintenance Treatment of Bipolar Disorder? A Systematic Review and Recommendations from the ISBD/IGSLI Task Force on Treatment with Lithium. Bipolar Disord. 2019, 21, 394-409. [CrossRef] [PubMed]

44. Nowicki, M.O.; Dmitrieva, N.; Stein, A.M.; Cutter, J.L.; Godlewski, J.; Saeki, Y.; Nita, M.; Berens, M.E.; Sander, L.M.; Newton, H.B.; et al. Lithium Inhibits Invasion of Glioma Cells; Possible Involvement of Glycogen Synthase Kinase-3. Neuro Oncol. 2008, 10, 690-699. [CrossRef]

45. Vidal, F.; de Araujo, W.M.; Cruz, A.L.; Tanaka, M.N.; Viola, J.P.; Morgado-Díaz, J.A. Lithium Reduces Tumorigenic Potential in Response to EGF Signaling in Human Colorectal Cancer Cells. Int. J. Oncol. 2011, 38, 1365-1373. [CrossRef]

46. Ronchi, A.; Salaroli, R.; Rivetti, S.; Della Bella, E.; Di Tomaso, T.; Voltattorni, M.; Cammelli, S.; Ceccarelli, C.; Giangaspero, F.; Barbieri, E.; et al. Lithium Induces Mortality in Medulloblastoma Cell Lines. Int. J. Oncol. 2010, 37, 745-752. [CrossRef]

47. Erdal, E.; Ozturk, N.; Cagatay, T.; Eksioglu-Demiralp, E.; Ozturk, M. Lithium-Mediated Downregulation of PKB/Akt and Cyclin E with Growth Inhibition in Hepatocellular Carcinoma Cells. Int. J. Cancer 2005, 115, 903-910. [CrossRef]

48. Beyaert, R.; Vanhaesebroeck, B.; Suffys, P.; Van Roy, F.; Fiers, W. Lithium Chloride Potentiates Tumor Necrosis Factor-Mediated Cytotoxicity in Vitro and in Vivo. Proc. Natl. Acad. Sci. USA 1989, 86, 9494-9498. [CrossRef]

49. Borriello, A.; Caldarelli, I.; Speranza, M.C.; Scianguetta, S.; Tramontano, A.; Bencivenga, D.; Stampone, E.; Negri, A.; Nobili, B.; Locatelli, F.; et al. Iron Overload Enhances Human Mesenchymal Stromal Cell Growth and Hampers Matrix Calcification. Biochim. Biophys. Acta 2016, 1860, 1211-1223. [CrossRef]

50. Iolascon, A.; Giordani, L.; Moretti, A.; Tonini, G.P.; Lo Cunsolo, C.; Mastropietro, S.; Borriello, A.; Della Ragione, F. Structural and functional analysis of cyclin-dependent kinase inhibitor genes (CDKN2A, CDKN2B, and CDKN2C) in neuroblastoma. Pediatr. Res. 1998, 43, 139-144. [CrossRef]

51. Iolascon, A.; Giordani, L.; Moretti, A.; Basso, A.; Borriello, A.; Della Ragione, F. Analysis of CDKN2A, CDKN2B, CDKN2C and cyclin D gene status in hepatoblastoma. Hepatology 1998, 27, 989-995. [CrossRef] [PubMed]

52. Livak, K.J.; Schmittgen, T.D. Analysis of Relative Gene Expression Data Using Real-Time Quantitative PCR and the 2(-Delta Delta C(T)) Method. Methods 2001, 25, 402-408. [CrossRef] [PubMed]

53. Borriello, A.; Caldarelli, I.; Bencivenga, D.; Cucciolla, V.; Oliva, A.; Usala, E.; Danise, P.; Ronzoni, L.; Perrotta, S.; Della Ragione, F. p57Kip2 is a Downstream Effector of BCR-ABL Kinase Inhibitors in Chronic Myelogenous Leukemia Cells. Carcinogenesis 2011, 32, 10-18. [CrossRef] [PubMed]

(C) 2020 by the authors. Licensee MDPI, Basel, Switzerland. This article is an open access article distributed under the terms and conditions of the Creative Commons Attribution (CC BY) license (http://creativecommons.org/licenses/by/4.0/). 